a strain of embryonated eggs isolated from faeces gave symptoms at a very low level : I ooo eggs/ pig.

- 25 strains isolated in our area were not really pathogenic if pulmonary lesions on mice are the criteria (BROWN and CHAX).

- Strains isolated from faeces are ineffective on mice, but highly pathogenic on swine. They could be considered as more harmful for swine than those coming from dissection or from laying, but cannot be selected on mice.

- It is necessary to give less than 500 eggs/piglet if the eosinophilic reaction has to be avoided. For high numbers this reaction is strong, but short in time.

In contrast with natural infestation so easy to bring about by mere cleterioration of the hygienic conditions, experimental infestation is difficult to obtain as the parasites go through the small intestine and donat remain inside this organ at a regular level.

However, liver or lung passage is quite easy to control and manage.

\title{
Swine gastro-intestinal parasites in France. Contribution to the epidemiology of Hyostrongylus rubidus after worm counts in adult sows and boars at the Slaughter-House
}

\author{
J. P. RAYNAUD \\ Station de Recherches et Développement vétérinaire, \\ Pfizer International, \\ B. P. 42,3r400 Amboise (France)
}

Stomach parasites and egg counts in adult sows and boars from family breedings and small size units were controlled.

Among 4075 stomachs examined, 27.9 P. 100 (I I 37) were found with worms. Out of 33 animals with parasites in the stomach, egg counts were important for Ascaris, Oesophagostomum and Hyostrongylus.

For an average of 573 Hyostrongylus eggs/gramme an average of 64 66 I Hyostrongylus including $4^{1} 6 I_{4}$ adults (values from 360 to 205600 ) was found in the stomach. Those figures are considerable.

\section{Homocytotropic antibodies in the pig}

\author{
J. J. METZGER, P. ROLZE, Ch. BOURDIEU and MI. HOUDAYER
}

Laboratoire de Pathologie porcine, I. N. R. A.,

78850 Thiverval-Grignon

Immunization of pigs with hen egg-white lysozyme in the presence of complete Freund's adjuvant gives rise to homocytotropic antibodies the kinetics of which parallel those of early antibodies. Through gel-filtration, however, those reaginic antibodies bchaved as $7 \mathrm{~S}$ molecules. 
The test of passive cutaneous anaphylaxis was sensitive to the action of Sodium chromoglycate while the immediate hypersensitivity reactions like Arthus, were not sensitive to it nor to antihistamics.

The homocytotropic antibody titer was not dependant on precipitating antilysozymo antibodies as revealed by passive hemagglutination tests. However, certain conditions of the immunization procedure may enhance reaginic antibodies : inoculation route, type of adjuvants.

Anaphylactic shocks were frequently observed at the antigen booster injection : the intravenous route leading usually to the animal's death. The intranasal or per buccal administration of antigen never gave such pathological symptoms.

\title{
VIII. - Physiology OF REPRODUCTION
}

\section{Birth mechanisms in the sow. Hormonal balanees before and after parturition}

\author{
J. FEVRE, M. TERQUI* and M. J. BOSC* \\ Station centrale de Physiologie animale, I. N.R. A., C. N.R. Z., \\ 78350 Jouy en Josas \\ * Station de Physiologie de la Reproduction, I. N. R. A., \\ B. P. 1, Nouzilly, 37380 Monnaie
}

The amount of progesterone required for maintenance of pregnancy is secreted at a constant level during almost whole pregnancy. During the pre partum period, (7 days prior to farrowing) there is a fall in the maternal blood levels of progesterone (from $15 \mathrm{ng} / \mathrm{ml}$ to $2 \mathrm{ng} / \mathrm{ml}$ ). Simultaneously, the foetal blood level of cortisol increases in a spectacular way (from $20 \mathrm{ng} / \mathrm{ml}$ to 2 Io $\mathrm{ng} / \mathrm{ml}$ at birth). If pregnancy is prolonged beyond the normal birth date by foztal hypophysectomy, the foetal blood level of cortisol remains very low without any rise, whereas the maternal blood level of progesterone remains high. It therefore seems that the rise in the foetal blood levels of glucocorticosteroids plays a part in the mechanisms of luteolysis.

In the maternal blood plasma, oestradiol-I $7 \beta$ does not exhibit any significant variations until the day before farrowing, whereas the level of oestrone increases progessively. Within the hours prior to parturition, there is a rapid increase in the maternal blood levels of these oestrogens (until $4 \mathrm{ng} / \mathrm{ml}$ for oestrone and $500 \mathrm{pg} / \mathrm{ml}$ for oestrasliol- 7 ; ). It can be assumed that these oestro. gens affect the uterine contractions and increase the synthesis and release of prostaglandins $F_{2 \alpha}$. Oestrogens, in particular by their action on prostaglandins $\mathrm{F}_{2 x}$ which are able to bring about premature farrowing in the sow, play an important part in the mechanisms of parturition.

$$
\text { Reçu pour publication en mai } 1975 .
$$

